\title{
Is There a Swiss Price Puzzle?
}

\author{
Daniel Kaufmann ${ }^{\mathrm{b}}$ and Sarah $_{\text {Lein }}{ }^{c}$
}

JEL-Classification: E31, E4, E5, C38

Keywords: monetary policy transmission, price puzzle, cost channel, FAVAR

\section{Introduction}

The effect of monetary policy on prices and output is traditionally analysed in vector autoregressions (VARs). A counter-intuitive result emerging in these VARs is that prices tend to increase after a monetary policy tightening; EICHENBAUM (1992) referred to this as the price puzzle. The literature has proposed various explanations for this result (for an overview, cf. WALSH, 2003, Chapter 1). One is that prices do indeed rise after a monetary policy tightening because there is a cost channel of monetary policy. Another is that the price puzzle is an econometric artefact. A VAR may be misspecified because it does not include all information that is available to the monetary authority.

The purpose of this paper is to shed light on both arguments by estimating a factor-augmented VAR (FAVAR). Bernanke, Boivin and Eliasz (2005) demonstrate that the FAVAR is capable of eliminating the price puzzle because it includes more information than a traditional VAR. They find no evidence of a price puzzle for the aggregate price level. Using the same method, Borvin, Giannoni and Minov (2009) examine the responses of disaggregate price

a We thank Gregor Bäurle, Sandra Eickmeier, Marc Giannoni, Sylvia Kaufmann, Carlos Lenz, Matthias Lutz, Klaus Neusser, Barbara Rudolf, Frank Schmid, Peter Tillmann, Mathias Zurlinden, two anonymous referees, participants of the YSEM meeting, the SSES annual meeting, the BuBa-OeNB-SNB workshop and the SNB Brown Bag workshop for helpful discussions and suggestions. An earlier version was published as SNB Working Paper 2011-7 titled "Sectoral Inflation Dynamics, Idiosyncratic Shocks and Monetary Policy". Andreas Bachmann and Andrea Schnell provided excellent research assistance. The views expressed in this paper are those of the authors and not necessarily those of the Swiss National Bank.

b Swiss National Bank, Börsenstrasse 15, P.O. Box, CH-8022 Zürich, Switzerland. E-mail: daniel.kaufmann@snb.ch.

c Swiss National Bank, Börsenstrasse 15, P.O. Box, CH-8022 Zürich, Switzerland. E-mail: sarah.lein@snb.ch. 
indices to idiosyncratic and macroeconomic shocks. While idiosyncratic shocks are incorporated quickly into prices, macroeconomic shocks have more persistent effects. In this paper, we combine the two contributions and derive disaggregate price responses to a monetary policy shock to examine the price puzzle at the disaggregate level. Because the FAVAR is more robust to misspecification this allows us to identify sectors where the price puzzle emerges from the cost channel of monetary policy.

Our main results can be summarised as follows. At the aggregate level, the price puzzle is an artefact. We do not reject that the price level declines monotonically after a monetary policy tightening. But the decline is delayed by at least four quarters. This result holds, whether we look at the response of the aggregate CPI or at an average response of disaggregate prices. We then show that this is because the FAVAR includes more information than a traditional three-variable VAR.

However, at a disaggregate level, there is evidence for a price puzzle. On the one hand, rents increase significantly after a monetary policy tightening. This is because there are legal provisions in Switzerland which link rents to mortgage rates. On the other hand, we find positive price responses for durable goods. This suggests that a cost channel of monetary policy exists in sectors with larger inventories.

The remainder of this paper is structured as follows. The FAVAR approach and the data are presented in Sections 2 and 3, respectively. Section 4 discusses the results and Section 5 concludes.

\section{Methodology}

We follow Bernanke, Boivin and Eliasz (2005) and Boivin, Giannoni and Minov (2009) and use a FAVAR to analyse price responses to a monetary policy shock. Compared to a traditional VAR, the FAVAR exploits the information content of a considerably larger set of macroeconomic variables. In addition, we can analyse the response of any of these variables to an identified monetary policy shock.

We assume that the Swiss economy can be summarised by a vector $\mathrm{C}_{t}$ of common components following the transition equation

$$
\mathbf{C}_{t}=\Phi(L) \mathbf{C}_{t-1}+\boldsymbol{v}_{t},
$$

where $\mathrm{C}_{t}=\left[\mathrm{F}_{t}^{\prime} R_{t}\right]^{\prime}, \Phi(L)$ is a lag polynomial and $\boldsymbol{v}_{t}$ is a zero-mean i.i.d. process. Only one of the common components is perfectly observed; we use the 
three-month Libor (3M Libor) as a measure of the monetary policy instrument $\left(R_{t}\right) .{ }^{1}$ The remaining common components are represented by a vector of unobserved factors $\mathrm{F}_{t}$, which we extract from a large data set.

The observation equation relates the common components to the data $\left(\mathbf{X}_{t}\right)$

$$
\mathrm{X}_{t}=\Lambda \mathrm{C}_{t}+\mathbf{e}_{t}
$$

where $\Lambda$ is a matrix of factor loadings and $\mathrm{e}_{t}$ captures idiosyncratic disturbances. This set-up assumes that $\mathrm{X}_{t}$ are noisy measures of the underlying macroeconomic concepts we aim to estimate. The unobserved factors are extracted as the first $K$ principal components of $\mathrm{X}_{t}$ (cf. STOCK and WATSON, 2002). The factor loadings are then estimated using OLS.

Since the $3 \mathrm{M}$ Libor is an observed factor, we impose it on the data $\mathrm{X}_{t}$ as a common component using the recursive procedure suggested by BoIvin, Giannoni and Minov (2009). First, we obtain the first $K$ principal components from $\mathrm{X}_{t}$, denoted by $\mathbf{F}_{t}^{0}$. We then estimate the factor loadings on $R_{t}\left(\hat{\boldsymbol{\lambda}}_{R}^{0}\right)$ by regressing $\mathrm{X}_{t}$ on $\mathrm{F}_{t}^{0}$ and $R_{t}$. Next, we remove the common component of $R_{t}$ from $\mathrm{X}_{t}$ by calculating $\tilde{\mathrm{X}}_{t}^{0}=\mathrm{X}_{t}-\hat{\boldsymbol{\lambda}}_{R}^{0} R_{t}$. Then, we estimate $\mathrm{F}_{t}^{1}$ as the first $K$ principal components of $\tilde{\mathbf{X}}_{t}^{0}$. The procedure is repeated several times to obtain the final estimate of $\mathrm{F}_{t}$.

\section{Data}

We estimate the FAVAR using a balanced panel of quarterly data from Q1 1978 to Q3 2008. The data include 137 macroeconomic time series and 140 of the price indices underlying the Swiss CPI. ${ }^{2}$

The macroeconomic data set covers many aspects of the Swiss economy such as real activity, the labour market, housing and financial markets. In addition, we include survey information, mostly covering real activity, consumer confidence and price expectations.

The price data set is based on index items obtained from the Swiss Federal Statistical Office (SFSO). An index item is the lowest level at which the SFSO calculates price indices and expenditure weights. We aggregate some of the index

1 The Swiss National Bank sets an operational target range for its chosen reference interest rate, the 3M Libor (cf. e.g. Jordan, Peytrignet and Rossi, 2010). Usually, it aims to hold the 3M Libor in the middle of that range.

2 A full list of the data and a detailed description of transformations are available upon request. 
items to a higher level because the SFSO revised the CPI basket several times during the sample period to adapt the basket to changing consumer preferences. ${ }^{3}$ In these revisions, some index items were discarded, added, merged or split up.

Table 1: Average Weights of Price Data

\begin{tabular}{lc}
\hline Category & Weight \\
\hline Total CPI & 90.6 \\
Services excluding rents & 25.8 \\
Rents & 19.5 \\
Non-durable goods & 27.9 \\
Semi-durable goods & 10.1 \\
Durable goods & 7.3 \\
\hline
\end{tabular}

Notes: The table shows average weights for the 140 CPI index items included in the sample. They are aggregated to various sectors and averaged over the sample period.

Our price data cover more than $90 \%$ of the Swiss CPI at average weights (cf. Table 1). The remaining $10 \%$ are discarded because we are not able to attribute all available index items to one of our categories. Moreover, we exclude administered prices such as public transport fees and postal services.

Although the Swiss CPI is published on a monthly basis, not all prices are actually collected every month. If no survey takes place, the SFSO carries forward the index value of the last month. This hampers transformations such as $\log$ differences, seasonal adjustment and aggregation to a quarterly frequency. The SFSO has increased the survey frequency substantially in recent years and most of the CPI basket is now collected monthly.

To account for the irregular survey frequency, we interpolate the missing observations. ${ }^{4}$ For every price index we set up a time-series model in terms of the

3 The Swiss CPI is a Laspeyres index. Therefore, the expenditure weights and the base year change only at major revisions of the CPI basket. To aggregate the index items, we use the corresponding time-varying expenditure weights. For each of our 140 categories, we set the underlying price indices to 100 in the corresponding base years and then take weighted averages. The resulting price indices are then linked in every base year. As of May 2000, the Swiss $\mathrm{CPI}$ is a Laspeyres index with weights changing annually.

4 A technical discussion of the interpolation method is available upon request. 
unobserved monthly changes. Based on the Kalman filter, we estimate the parameters by maximum likelihood (cf. e.g. Hamilton, 1994). The Kalman smoother yields an estimate of the unobserved monthly changes. Finally, the estimated monthly changes are transformed back to levels, seasonally adjusted and aggregated to quarterly frequency.

The data should be stationary. We therefore test for unit roots by running an ADF test (Dickey and Fuller, 1979) and a KPSS test (Kwiatkowski et al., 1992). ${ }^{5}$ Both tests suggest that most of the prices are non-stationary. Therefore we take $\log$ differences of the price data. ${ }^{6}$ Moreover, we use log differences of the macroeconomic time series when the tests suggest that there is a unit root. All interest rates, spreads and real exchange rates are used in levels.

The question of how many factors to extract from the data can be answered by the test suggested by BAI and $\mathrm{NG}_{\text {(2002). }}{ }^{7}$ Because we impose $R_{t}$ as a common component, we test for the number of factors in $\tilde{\mathrm{X}}_{t}=\mathrm{X}_{t}-\hat{\boldsymbol{\lambda}}_{R} R_{t}$ rather than $\mathrm{X}_{t}{ }^{8}$ Three factors seem to summarise the information content of $\mathbf{X}_{t}$ well. Adding the $3 \mathrm{M}$ Libor, we end up with four common components (cf. Figure 1). As Bernanke, Boivin and Eliasz (2005) emphasise, the test does not tell us how many factors to include in the VAR to capture the relevant dynamics, but only how many factors capture the information in the data set well. However, we have experimented with more factors and the results remain qualitatively the same.

Although we do not strictly identify the factors as economic concepts they seem to capture at least as much information as a traditional three-variable VAR with GDP growth, CPI inflation and a short-term interest rate. The absolute size of the factor loadings give us indications which part of the economy the factors can be related to (cf. Table 2). The first factor mostly loads on price series. It may therefore capture general inflation dynamics. The second factor loads on data covering the real economy, such as orders, sales or business confidence. Most of the factor loadings are negative, that is, the factor is negatively correlated with real activity. This is also supported by the fact that the factor is strongly correlated with one of the output gap measures calculated regularly by the Swiss National Bank

5 The test results are available upon request.

6 The ADF test has low statistical power to identify unit roots, so we visually inspect those prices for which the test rejects a unit root; they often appear to be non-stationary. We therefore use log differences for all prices.

7 We apply the first criterion proposed by BAI and $N_{G}$ (2002). The other two criteria imply the same number of factors.

8 STоск and Watson (2005) recommend a similar procedure when imposing a lag on the observation equation. 


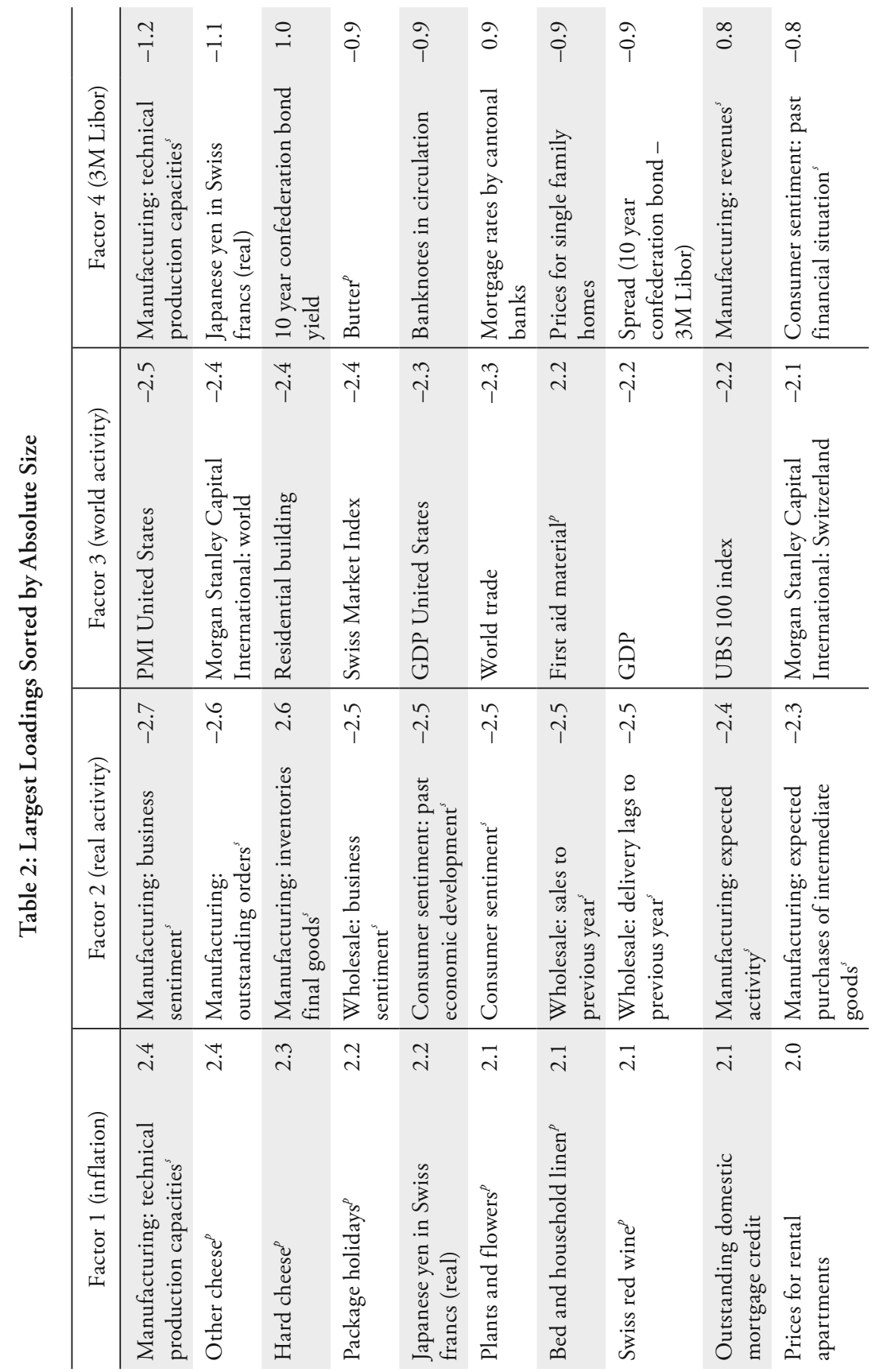




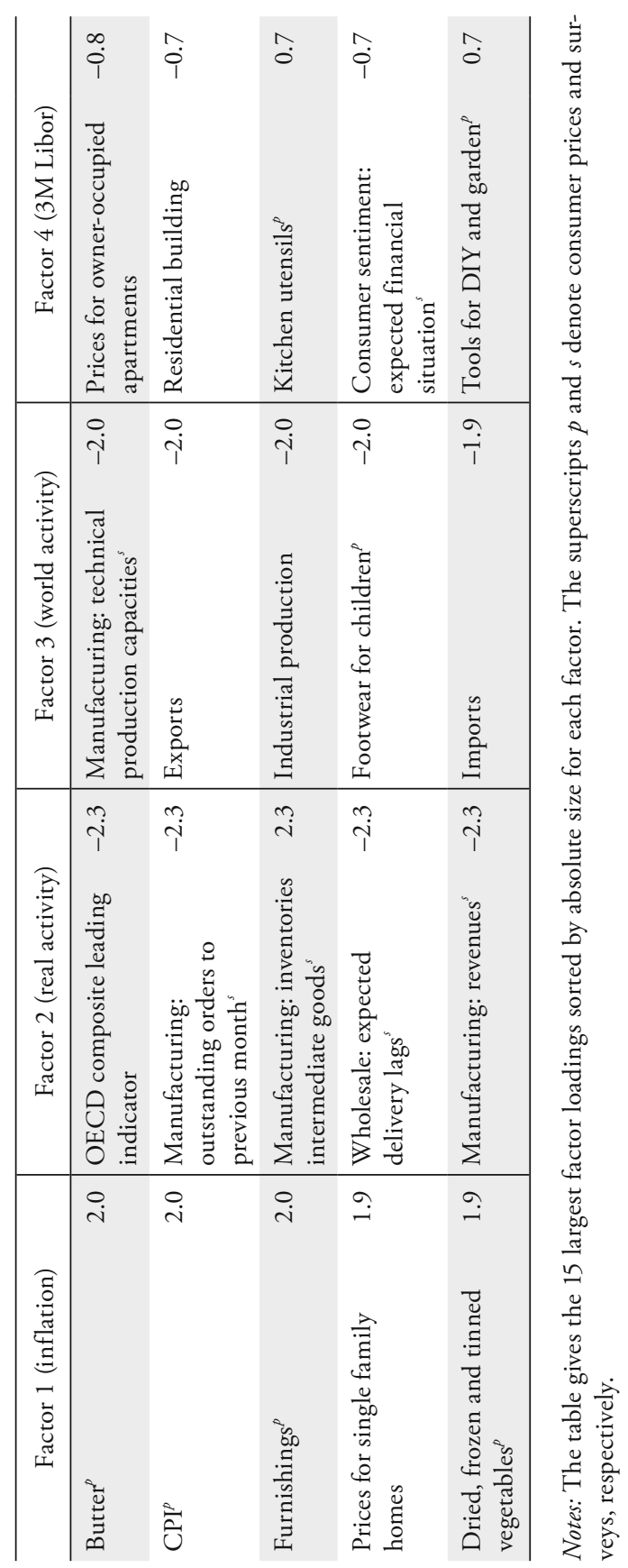




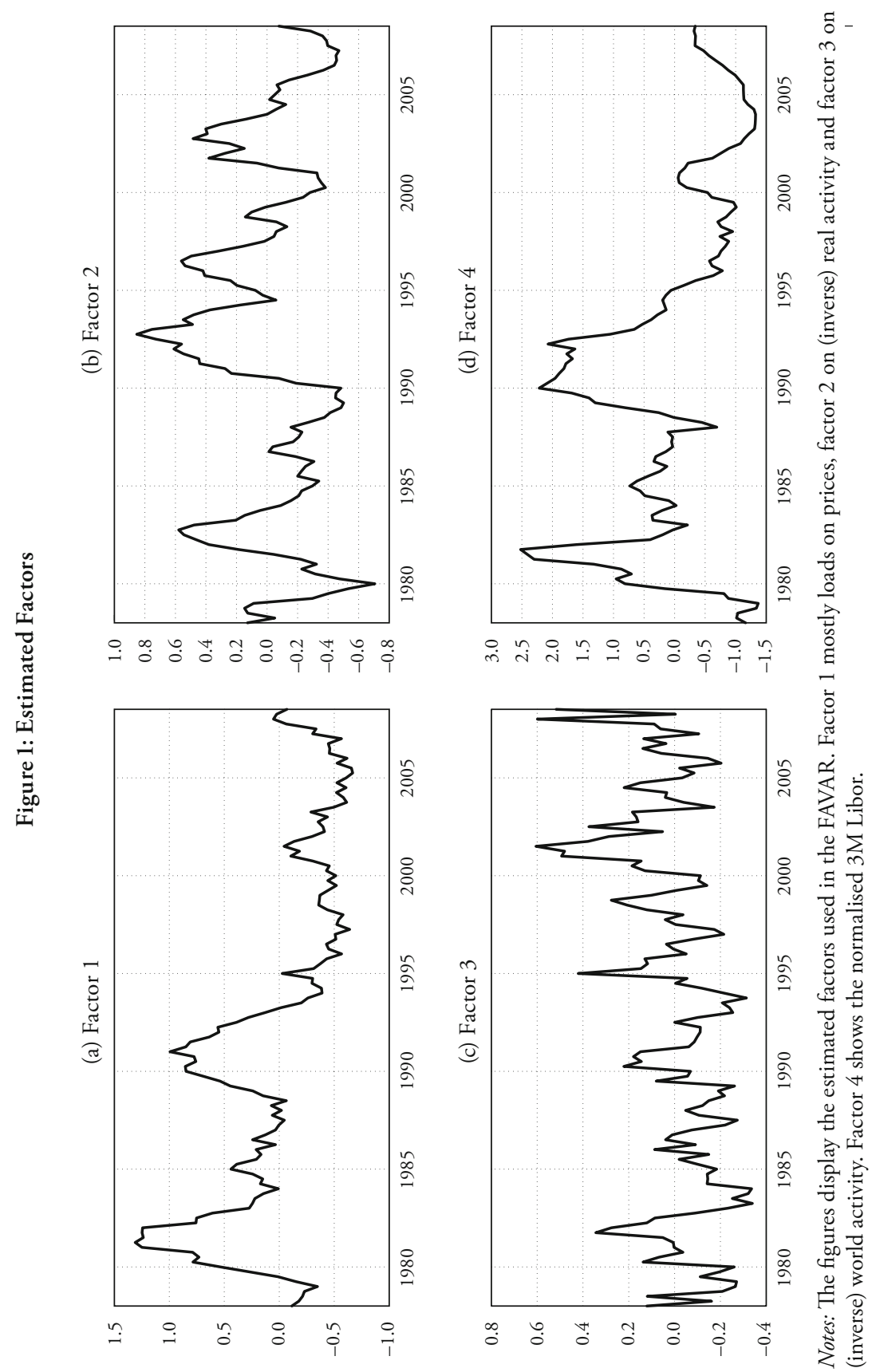


(contemporaneous correlation: -0.66 ; two quarters ahead correlation: -0.78 ). The third factor mostly loads on international data and Swiss data related to world activity. Again, most factor loadings are negative. By construction, the fourth factor is the $3 \mathrm{M}$ Libor. It loads not only on the interest rate spread, mortgage rates and residential building, but also on technical capacities and price series.

\section{Results}

The FAVAR allows us to analyse the effect of monetary policy on a large number of variables. The transition equation (1) is estimated with five lags and the monetary policy shock is identified by recursive ordering. 'We assume that the monetary policy shock does not affect the common components within one period. Thus, monetary policy surprises take some time to be reflected in slow-moving variables such as real activity or inflation; but the monetary authority can react immediately to changes in the economic environment.

\subsection{VAR Misspecification}

Many studies suggest that the price puzzle is due to VAR misspecification. These studies avoid the price puzzle by including a commodity price index (SIMS, 1992; Eichenbaum, 1992), money (Leeper and Zha, 2001; Assenmacher-Wesche, 2008), an output gap (Giordani, 2004) or inflation expectations (CASTELnUovo and Surico, 2010). The FAVAR encompasses these arguments because it includes more information than a traditional VAR.

The impulse responses of the factors to a $25 \mathrm{bp}$ increase in the $3 \mathrm{M}$ Libor are broadly in line with economic intuition (cf. Figure 2). ${ }^{10}$ The factor mostly loading on prices exhibits a hump-shaped response (panel a). That is, it first rises but then declines after roughly four quarters. Although there is no sustained positive response, this indicates that some prices in our sample may still exhibit a price puzzle. As one would expect, the factor that is inversely related to real activity

9 In what follows, we define the monetary policy shock as a surprise increase in the 3M Libor. However, the impulse responses for a decrease are symmetric in our set-up.

$1080 \%$ and $90 \%$ confidence intervals are given as shaded areas. They are derived via the biascorrected bootstrap algorithm proposed by KILIAN (1998). We ignore the fact that the factors are estimated and therefore subject to uncertainty. However, the confidence intervals are still correct if the number of time series in $\mathrm{X}_{t}$ is large relative to the number of time periods (cf. BAI and $\left.N_{G}, 2004\right)$. 


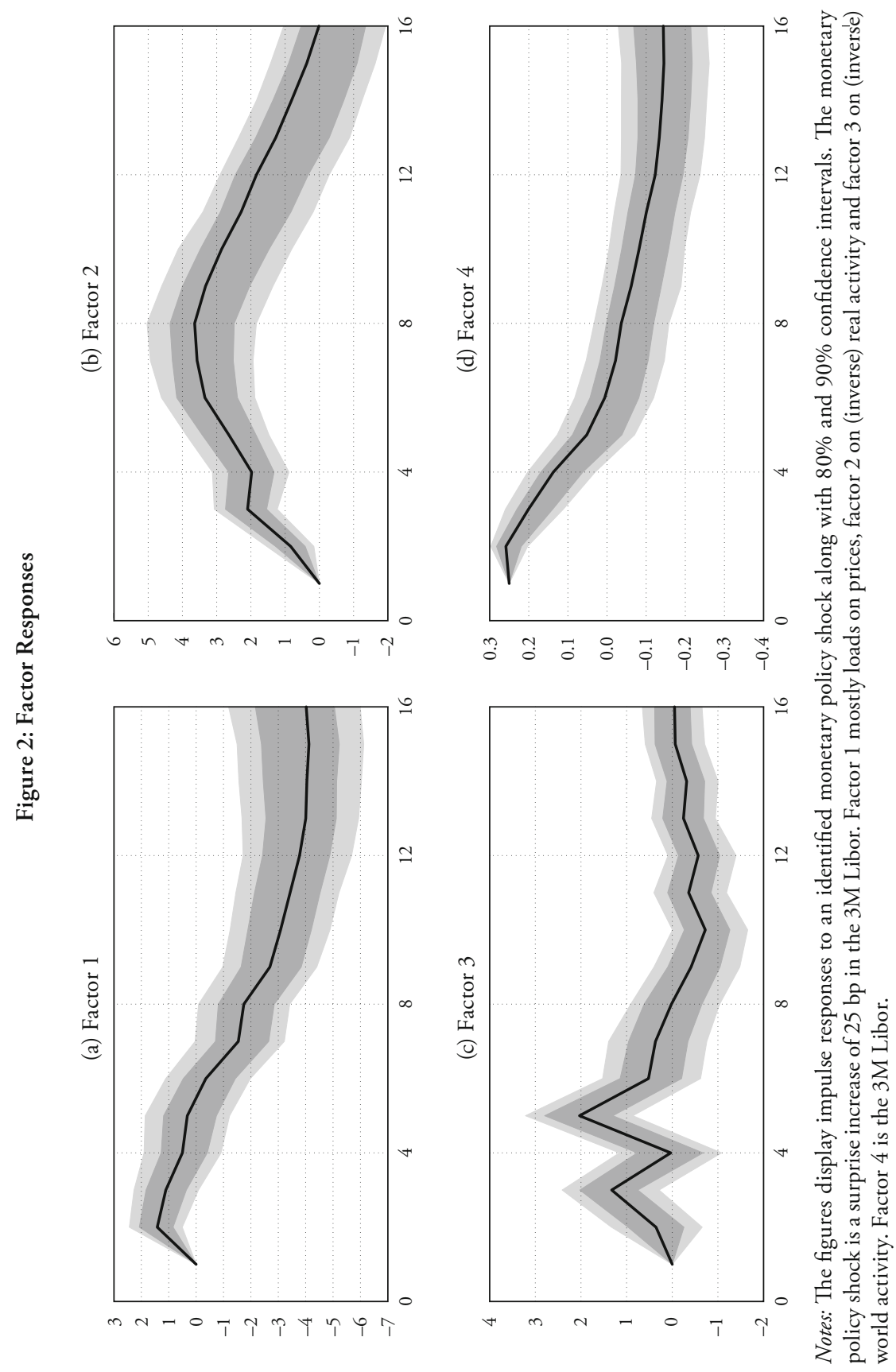


increases after a contractionary monetary policy shock (panel b). While prices appear to be permanently reduced, there is only a transitory effect on real activity. Factor 3 does not react systematically to a monetary policy shock (panel c). The 3M Libor displays some inertia after the initial shock. It first moves sideways and then returns to zero after six quarters (panel d).

Figure 3: Response of the CPI

(a) CPI

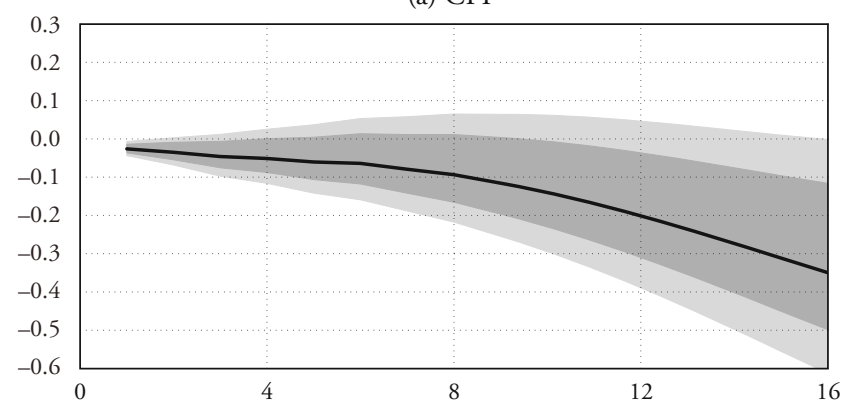

(b) Weighted average of index items

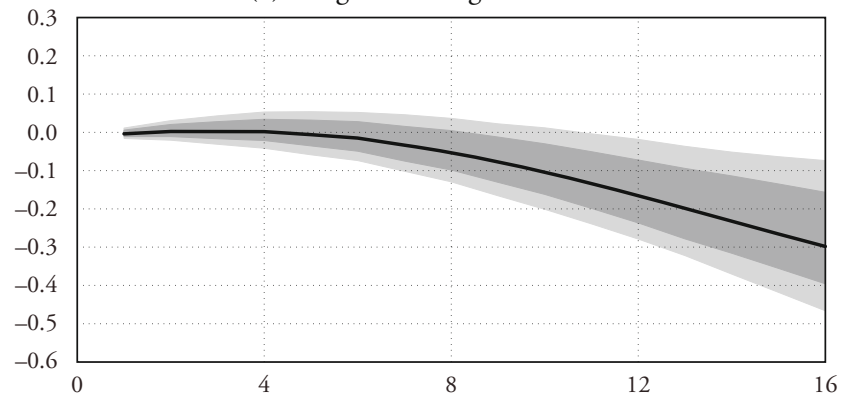

Notes: The figures display accumulated impulse responses to an identified monetary policy shock along with $80 \%$ and $90 \%$ confidence intervals (in percent). The monetary policy shock is a surprise increase of $25 \mathrm{bp}$ in the $3 \mathrm{M}$ Libor.

From these factor responses, we can calculate the responses of specific variables in our data set via observation equation (2). ${ }^{11}$ Figure 3 illustrates the response of the aggregate price level to a monetary policy shock. Although the response is sluggish, there is no evidence of a price puzzle (panel a). Looking at the weighted

11 More precisely, we calculate the response of the common component of these variables. 
average response of the 140 index items corroborates this finding (panel b). Focusing on the point estimate, we find a response that is delayed by four quarters. But we would not reject that a monetary policy shock may take even longer to affect prices. ${ }^{12}$

It is possible that we do not find a price puzzle because the FAVAR includes more information than a traditional VAR. To examine this possibility, we augment a three-variable VAR with our estimated factors. Our FAVAR nests this VAR, and therefore we can assess whether the additional information reduces the price puzzle (cf. Bernanke, Boivin and Eliasz, 2005).

The results suggest that the price puzzle is an econometric artefact because we do not include enough information in a traditional three-variable VAR. Figure 4 displays the responses for a VAR with GDP growth, CPI inflation and the $3 \mathrm{M}$ Libor (solid lines). The CPI rises permanently after a contractionary monetary policy shock, and thus there is a price puzzle. However, if we augment the VAR with one or two factors, the price puzzle disappears (dashed and dotted lines). Meanwhile, the responses of GDP and the 3M Libor are not greatly affected.

\subsection{Swiss Rent Law}

Although the price puzzle disappears for the aggregate CPI, we still find positive price responses in some sectors. In particular, the initial rise in rents can be explained by legal provisions in Switzerland.

Switzerland is special in that rents under existing contracts are partially linked to mortgage rates by law. Owners of a rental apartment have to adjust rents under existing contracts when mortgage rates change. Thus, interest rate movements may feed directly into the CPI. Moreover, rents are partially indexed to the CPI. This may have an additional reinforcing effect.

Rents pick up by almost $0.2 \%$ after a monetary policy tightening (cf. Figure 5 , panel a). This coincides with mortgage rates rising by $12 \mathrm{bp}$ on impact (panel b). Rents thus partly explain the delayed response of the CPI to a monetary policy shock. The CPI excluding rents (panel c) shows a faster decline than the total CPI (cf. Figure 3).

A $12 \mathrm{bp}$ increase in mortgage rates would, by law, allow for a $1 \%$ increase in rents, which is five times larger than what we estimate. First, this is because the law covers only rents under existing contracts. There is more leeway to set rents

12 This is in line with the idea that prices are adjusted irregularly. Kaufmann (2009) finds that the average duration between two price adjustments is slightly more than one year. 


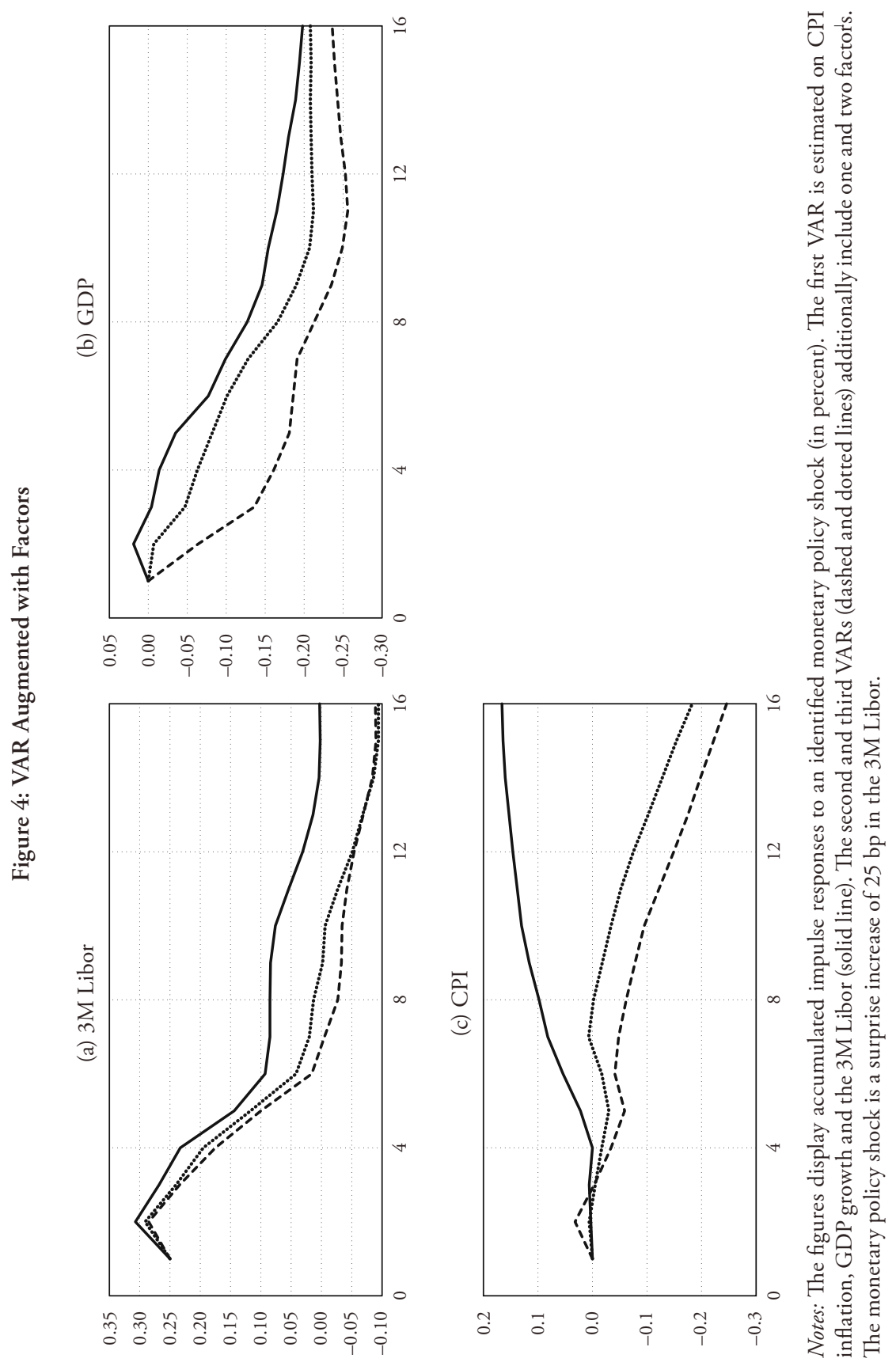




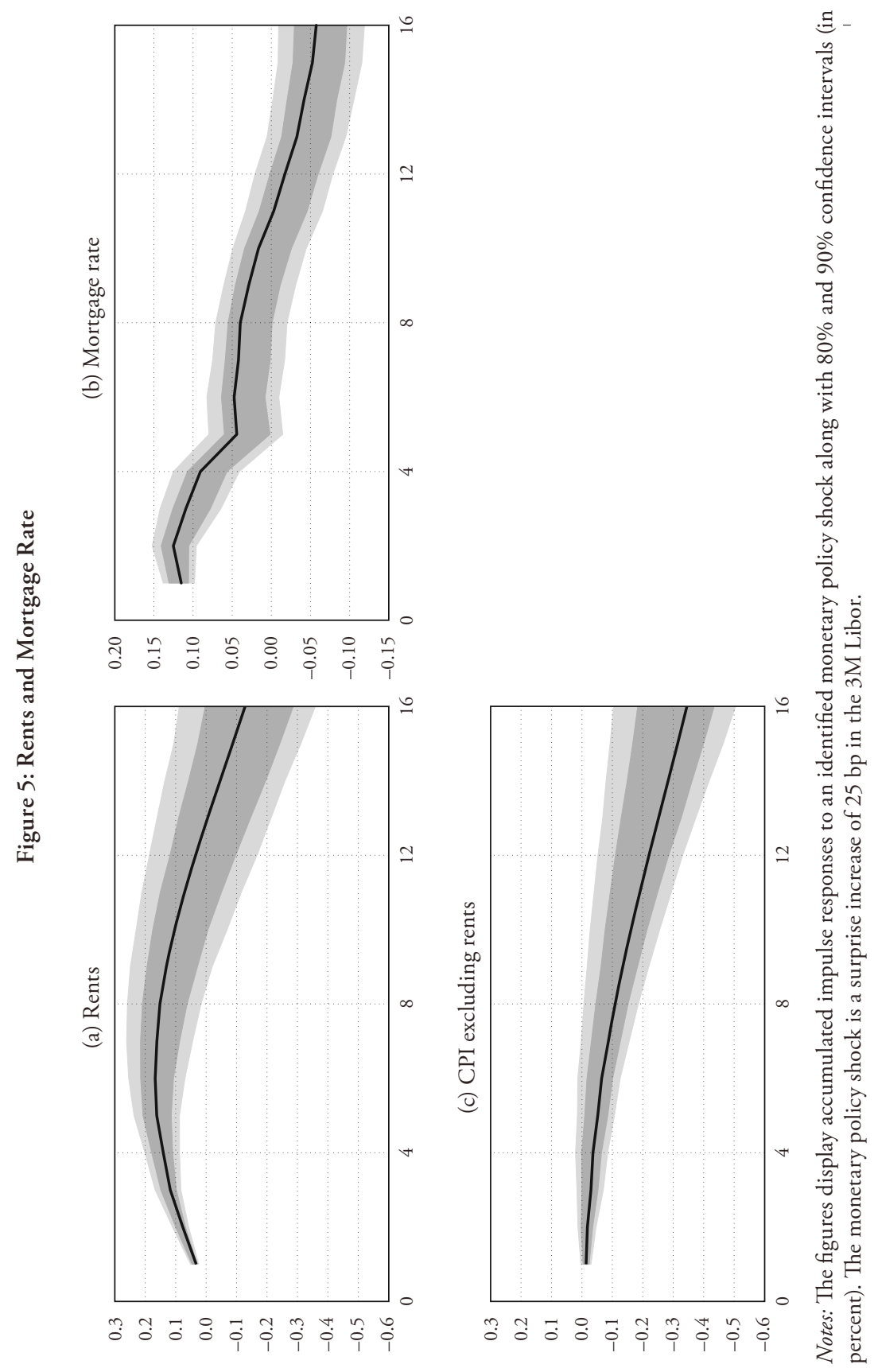

Swiss Journal of Economics and Statistics, 2012, Vol. 148 (1) 
under newly negotiated contracts. Second, this is because there is no automatic adjustment; the owner or tenant has to file an application with the corresponding counterparty. Our estimates suggest this right is rarely exercised. STALder (2003) also finds that mortgage rate changes do not fully feed into higher rents. According to his estimates, a $10 \mathrm{bp}$ increase in mortgage rates leads to a $0.23 \%$ increase in rents on impact and a $0.49 \%$ increase in the long term.

\subsection{Cost Channel}

Although rents explain a major part of the delayed response of the Swiss CPI, durable goods also display a price puzzle. They show a significant short-run increase and start to fall after eight quarters (Figure 6, panel a). By contrast, other prices do not exhibit a sustained increase in the price level. Prices for services excluding rents display the most sluggish behaviour and decline only after eight quarters. Meanwhile, semi-durable goods prices start to decline after one year and non-durable goods prices decline immediately.

How can we explain the hump-shaped responses for durable goods? Theoretically, a hump-shaped price response may occur if higher interest rates translate into higher marginal costs of production. This is called the cost channel of monetary policy transmission. ${ }^{13}$ One explanation of the cost channel mechanism is that firms have to pre-finance inventories via financial intermediaries. Thus, higher interest rates feed into higher prices as the real cost of inventories tends to increase in response to a monetary policy tightening. Arguably, inventory holdings are more important for durable goods than for non-durable goods, semi-durable goods and services. Therefore, durable goods may be particularly affected by the cost channel of monetary policy transmission.

This finding is in line with recent work using DSGE models. Henzel et al. (2009), for instance, show for the euro area that, although the cost channel does not produce a hump-shaped response, it helps to explain a delayed price response. Our results are consistent with this. While there is no price puzzle at the aggregate level, we find that in sectors where inventory holdings play a larger role, a hump-shaped response emerges that leads to a more sluggish response of the aggregate price level.

13 For theoretical and empirical results on the cost channel of monetary policy transmission cf. e.g. Barth and Ramey (2002), Ravenna and Walsh (2006), Chowdhury, Hoffmann and Schabert (2006), Rabanal (2007), Tillmann (2008) and Henzel et al. (2009). 


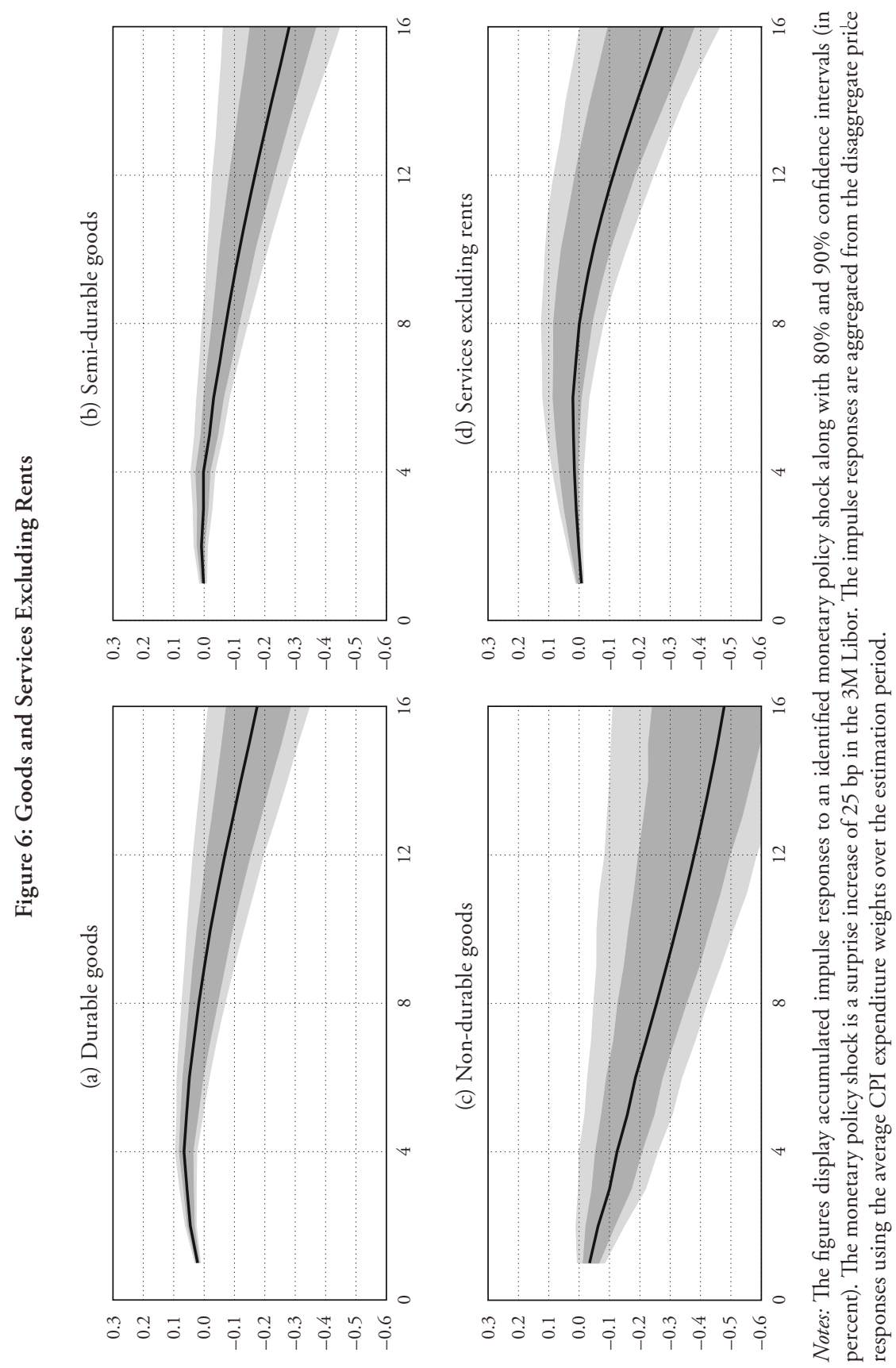




\section{Conclusions}

This paper identifies monetary policy shocks in a FAVAR for Switzerland. In line with findings for the US, the response of the aggregate CPI to a monetary policy shock no longer displays a price puzzle when using a FAVAR. The aggregate CPI starts to fall four quarters after the monetary policy tightening. This is because the FAVAR includes more information than a traditional VAR and therefore avoids misspecification.

We take the analysis a step further and show that there remains a price puzzle in some sectors. First, the price puzzle is partly a result of legal provisions in Switzerland that link rents to mortgage rates. Therefore, the CPI excluding rents declines faster after a monetary policy tightening than the aggregate CPI.

Second, prices of durable goods also rise after a monetary policy tightening. This may be related to the cost channel of monetary policy. One explanation of the cost channel mechanism is that firms have to pre-finance inventories via financial intermediaries. Thus, higher interest rates feed into higher prices as the real cost of inventories tends to increase in response to a monetary policy tightening. Arguably, inventory holdings are more important for durable goods than for non-durable goods, semi-durable goods and services. Therefore, durable goods may be particularly affected by the cost channel of monetary policy transmission. As argued in theoretical work using DSGE models, the existence of a cost channel in a single sector does not necessarily lead to a rising aggregate price level; but the response of the aggregate price level to a monetary policy shock may then be more delayed.

\section{References}

Assenmacher-Wesche, Katrin (2008), "Modeling Monetary Transmission in Switzerland with a Structural Cointegrated VAR Model", Swiss Journal of Economics and Statistics, 144(2), pp. 197-246.

Bai, Jushan, and Serena Ng (2002), "Determining the Number of Factors in Approximate Factor Models”, Econometrica, 70(1), pp. 191-221.

BaI, Jushan, and Serena NG (2004), "Confidence Intervals for Diffusion Index Forecasts with a Large Number of Predictors", Mimeo.

Barth, Marvin J., and Valerie A. Ramey (2002), "The Cost Channel of Monetary Transmission", in NBER Macroeconomics Annual, Ben S. Bernanke and Kenneth Rogoff, eds, vol. 16, chap.4, pp. 199-256, Cambridge: MIT Press. 
Bernanke, Ben, Jean Boivin and Piotr S. Eliasz (2005), "Measuring the Effects of Monetary Policy: A Factor-Augmented Vector Autoregressive (FAVAR) Approach”, The Quarterly Journal of Economics, 120(1), pp.387-422. Boivin, Jean, Marc P. Giannoni and Ilian Mihov (2009), "Sticky Prices and Monetary Policy: Evidence from Disaggregated US Data”, American Economic Review, 99(1), pp. 350-384.

Castelnuovo, Efrem, and Paolo Surico (2010), "Monetary Policy, Inflation Expectations and the Price Puzzle", The Economic Journal, 120(549), pp. 1262-1283.

Chowdhury, Ibrahim, Mathias Hoffmann, and Andreas Schabert (2006), "Inflation Dynamics and the Cost Channel of Monetary Transmission", European Economic Review, 50(4), pp. 995-1016.

Dickey, David A., and Wayne A. Fuller (1979), "Distribution of the Estimators for Autoregressive Time Series with a Unit Root", Journal of the American Statistical Association, 74(366), pp.427-431.

Eichenbaum, Martin (1992), "Interpreting the Macroeconomic Time Series Facts: The Effects Of Monetary Policy': by Christopher Sims”, European Economic Review, 36(5), pp. 1001-1011.

Giordani, Paolo (2004), "An Alternative Explanation of the Price Puzzle", Journal of Monetary Economics, 51(6), pp. 1271-1296.

Hamilton, James D. (1994), Time Series Analysis, Princeton: Princeton University Press.

Henzel, Steffen, Oliver Hülsewig, Eric Mayer and Timo WollmershäuSER (2009), "The Price Puzzle Revisited: Can the Cost Channel Explain a Rise in Inflation after a Monetary Policy Shock?", Journal of Macroeconomics, 31(2), pp. 268-289.

Jordan, Thomas J., Michel Peytrignet and Enzo Rossi (2010), “Ten Years' Experience with the Swiss National Bank's Monetary Policy Strategy”, Swiss Journal of Economics and Statistics, 146(1), pp.9-90.

Kaufmann, Daniel (2009), "Price-Setting Behaviour in Switzerland: Evidence from CPI Micro Data", Swiss Journal of Economics and Statistics, 145(3), pp. 293-349.

Kilian, Lutz (1998), "Small-Sample Confidence Intervals for Impulse Response Functions", The Review of Economics and Statistics, 80(2), pp. 218-230.

Kwiatkowski, Denis, Peter C. B. Phillips, Peter Schmidt and Yongcheol SHIN (1992), "Testing the Null Hypothesis of Stationarity against the Alternative of a Unit Root: How Sure Are We that Economic Time Series Have a Unit Root?", Journal of Econometrics, 54(1-3), pp. 159-178. 
Leeper, Eric M., and Tao Zha (2001), "Assessing Simple Policy Rules: A View from a Complete Macroeconomic Model”, Federal Reserve Bank of St. Louis Review, 83(4), pp. 83-110.

Rabanal, Pau (2007), "Does Inflation Increase after a Monetary Policy Tightening? Answers Based on an Estimated DSGE model", Journal of Economic Dynamics and Control, 31(3), pp.906-937.

Ravenna, Federico, and Carl E. Walsh (2006), "Optimal Monetary Policy with the Cost Channel", Journal of Monetary Economics, 53(2), pp. 199-216.

Sims, Christopher A. (1992), "Interpreting the Macroeconomic Time Series Facts: The Effects of Monetary Policy", European Economic Review, 36(5), pp. $975-1000$.

Stalder, Peter (2003), "The Decoupling of Rents from Mortgage Rates: Implications of the Rent Law Reform for Monetary Policy", Swiss National Bank Quarterly Bulletin, 3, pp.44-57.

Stock, James H., and Mark W. Watson (2002), "Macroeconomic Forecasting using Diffusion Indexes", Journal of Business \& Economic Statistics, 20(2), pp. 147-162.

Stock, James H., and Mark W. Watson (2005), "Implications of Dynamic Factor Models for VAR Analysis”, NBER Working Paper No. 11467, National Bureau of Economic Research.

Tillmann, Peter (2008), "Do Interest Rates Drive Inflation Dynamics? An Analysis of the Cost Channel of Monetary Transmission", Journal of Economic Dynamics and Control, 32(9), pp. 2723-2744.

Walsh, Carl E. (2003), Monetary Theory and Policy, 2nd edn., Cambridge: MIT Press.

\section{SUMMARY}

This paper estimates the response of consumer prices to a monetary policy shock in Switzerland. We find that there is no evidence of a price puzzle at the aggregate level. This is because our factor-augmented vector autoregression (FAVAR) avoids misspecification by including more information than a traditional VAR. However, the response is still delayed by at least four quarters, partly because there is a price puzzle in some sectors. In particular, rents tend to rise after a monetary policy tightening because there are legal provisions in Switzerland which link them to interest rates. But durable goods prices also rise, which is consistent with the existence of a cost channel of monetary policy. 